\title{
EEF2K wt Allele
}

National Cancer Institute

\section{Source}

National Cancer Institute. EEF2K wt Allele. NCI Thesaurus. Code C119727.

Human EEF2K wild-type allele is located in the vicinity of $16 \mathrm{p} 12.2$ and is approximately 82

$\mathrm{kb}$ in length. This allele, which encodes eukaryotic elong ation factor 2 kinase protein, plays a role in the inhibition of protein translation. 